\title{
U.S.-China Trade War and Its Global Impacts
}

Dan Steinbock

\begin{abstract}
With high growth rates during the past two decades and the largest trade surplus with the United States, China is the primary target of the U.S. trade war efforts. Tariffs are the first shot in bilateral tensions that are multilateralizing and injuring global economic integration, coupled with ever more intense technology competition. The evolving global scenarios of U.S.-China trade and technology conflicts are the outcome of an ever more anxious America forsaking its multilateral cooperative stances for primacy doctrines. In the worst case, these conflicts may escalate into a "decoupling" of both economies and cause lasting global recession and new geopolitical confrontation. This gloomy scenario has become viable with the exceptional use of executive power by the post-9/11 U.S. administrations. The Trump administration, in particular, is predicated on "imperial presidency" that relies on an emergency status quo, new campaign finance, and "big money," which poses significant risks not only to U.S.-China relations, but also to American democracy and existing international order.
\end{abstract}

Dan Steinbock is the founder of Difference Group (www.differencegroup.net). He has served as Research Director of International Business at the India China and America Institute, as well as a Visiting Fellow at the Shanghai Institutes for International Studies (SIIS) and the EU Center in Singapore. His mailing address is: 195-15 Tianlin Road, Shanghai 200233, China. He can also be reached at info@differencegroup.net.

(c) 2018 World Century Publishing Corporation and Shanghai Institutes for International Studies China Quarterly of International Strategic Studies, Vol. 4, No. 4, 515-542

DOI: 10.1142/S2377740018500318

This is an Open Access article, copyright owned by the SIIS and WCPC. The article is distributed under the Creative Commons Attribution 4.0 (CC BY-NC) Licence. Further distribution of this work is permitted, provided the original work is properly cited and for non-commercial purposes. 
Keywords: Globalization; U.S.-China trade; intellectual property (IP); “state of exception"; "imperial presidency".

This article is adapted from the author's research project at SIIS on "China in the Era of Economic Uncertainty and Geopolitical Risk" during his visiting fellowship from 2017-2018.

\section{Rising U.S.-China Tensions and Waning Globalization}

Today, globalization led by the United States and other advanced economies is winding down, while China-fueled globalization, which is driven by emerging economies, has grown to be a complement. As "America First" policies surge in Washington, the attractiveness of the Asian Infrastructure Investment Bank (AIIB) and the BRICS ${ }^{1}$ New Development Bank (NDB) has significantly increased in developing economies. Nevertheless, both the Obama and Trump administrations, in contrast to their major trade partners and other Group of Seven (G7) members, have largely limited the U.S. from participation. Similarly, Washington has kept its distance from the China-led Belt and Road Initiative (BRI) despite its openness toward U.S. participation - President Trump even labeled the Initiative as "insulting." ${ }^{2}$

The U.S. goal may be to contain China's economic rise or divide Asia, or both, as evidenced by hardened sentiments ${ }^{3}$ and efforts to pressure China on its trade, investment and technological policies, while taking many "divide and rule" measures in the Asia-Pacific. On the economic front, for example, U.S. Secretary of State Mike Pompeo gave a speech on

${ }^{1}$ BRICS is the acronym coined for an association of five major emerging economies including Brazil, Russia, India, China and South Africa. Leaders of the BRICS nations have met annually since 2009 for policy coordination and deepening cooperation.

${ }^{2}$ Annie Karni, "Trump Rants Behind Closed Doors With CEOs," Politico, August 8, 2018, https://www.politico.com/story/2018/08/08/trump-executive-dinner-bedminster-china766609 .

${ }^{3}$ These sentiments are even reflected by the new harsher tone of international relations scholars. See, for example, Ashley J. Tellis, "Pursuing Global Reach: China's Not So Long March toward Preeminence," in Ashley J. Tellis et al., Strategic Asia 2019: China's Expanding Strategic Ambitions (Washington, D.C.: NBR, 2019). 


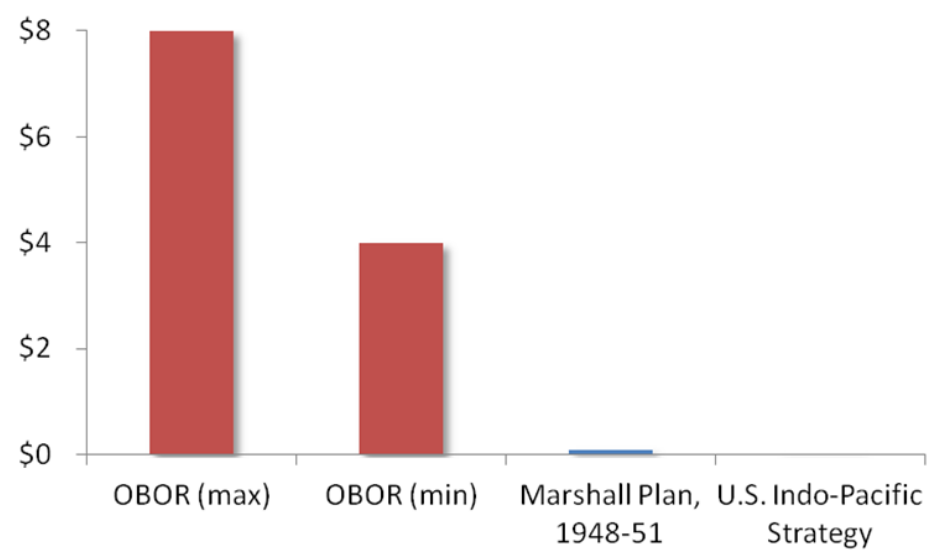

Fig. 1. Financial Inputs to the Indo-Pacific Vision, Marshall Plan, and China's BRI.

Source: Compiled by the author. Estimates are expressed in trillions of U.S. dollars. China's BRI, or "One Belt One Road (OBOR)," features maximum (OBOR, max) and minimum (OBOR, min) estimates based on relevant literature.

“America's Indo-Pacific Economic Vision" on July 30, 2018, in which he announced \$113 million in new U.S. initiatives to "support foundational areas of the future" in the regional economy, energy, and infrastructure. ${ }^{4}$ But the scale of the "Indo-Pacific Economic Vision" pales in comparison with the BRI, which involves far greater cumulative investments estimated at around $\$ 4$ trillion to $\$ 8$ trillion, ${ }^{5}$ dwarfing even the Marshall Plan from 70 years ago (as Pompeo alluded to), whose cumulative aid may have totaled $\$ 12$ billion, or about $\$ 180$ billion in today's dollar value (Figure 1).

Indeed, what Asia needs is not new geopolitical divisions, but a sustainable, long-term plan for accelerated economic integration and development, indicated by the overwhelming consensus among Asian countries on working to reach a free trade agreement of the Asia-Pacific

\footnotetext{
${ }^{4}$ The vision is a rehash of ideas that former Secretary of State John Kerry introduced a few years ago. Also, Pompeo bypassed the specifics of where the money would come from. See Mike Pompeo's speech on "America's Indo-Pacific Economic Vision" at the "Indo-Pacific Business Forum" in Washington, D.C. on July 30, 2018.

${ }^{5}$ For a comparison among the BRI, the U.S. Indo-Pacific Vision, and the Marshall Plan, see Dan Steinbock, "How the Indo-Pacific Vision Forgot Asian Development," China-US Focus, August 14, 2018, https://www.chinausfocus.com/finance-economy/how-the-indopacific-vision-forgot-asian-development.
} 
(FTAAP) that includes the United States. ${ }^{6}$ However, that is not what the Trump administration wants.

\section{U.S.-China Trade Tensions}

The United States and China are the world's leading powers in terms of the size of their economies, defense budgets, and global greenhouse gas emissions. Both nations are permanent members of the United Nations Security Council. In 2017, they were each other's largest trading partners. This bilateral relationship is perceived by many to be the most consequential in the world. The global importance of the U.S. and Chinese economies, as measured by their nominal gross domestic product (GDP), can be illustrated in two ways that will also illuminate the challenges of the ongoing power transition: one involves the rise of the Chinese economy relative to the U.S. GDP; the other focuses on the concomitant shifts in globalization.

In 2000, China's economy was barely a tenth of the U.S. GDP. But after China became a member of the World Trade Organization (WTO) in 2001, its export-led growth soared in the course of the 2000s, when its share of the U.S. economy more than tripled from 12 percent in 2000 to over 40 percent in 2010. The original Goldman Sachs estimate was that China would surpass the United States in the late 2020s (Figure 2a); and that remains the case under Xi Jinping's leadership, assuming current secular trend lines prevail (Figure 2b).

Yet there are two major caveats to the Goldman Sachs projections: the first involves international trade prospects amid rising U.S. protectionism; the second has to do with the impact of these trade actions on the consequent global prospects. After a year of threats, the Trump administration initiated a "tariff war" against China in March 2018. The measures became effective in early July 2018. What began with "national security reviews" on steel and aluminum soon extended to intellectual property rights and

${ }^{6}$ The idea of free trade in the Asia-Pacific has been around since 1966 when Japanese economist Kiyoshi Kojima advocated a Pacific free trade agreement. Many U.S. economists and scholars supported the idea. For instance, see C. Fred Bergsten, "Toward a Free Trade Area of the Asia Pacific," Remarks at the APEC CEO Summit Santiago, Chile, November 19, 2004, https://piie.com/commentary/speeches-papers/toward-free-tradearea-asia-pacific- 0 . 


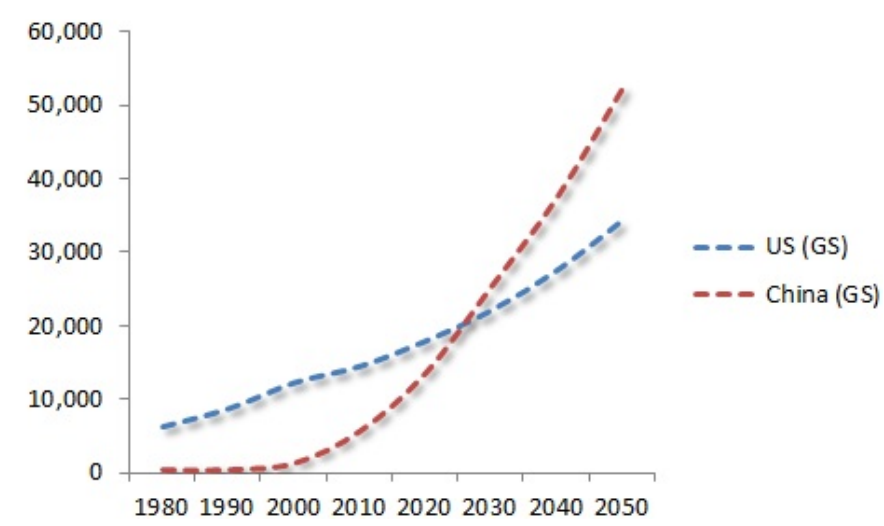

Fig. 2a. Expansion of U.S. and Chinese Economies, 1980-2050E Goldman Sachs BRICS Projection

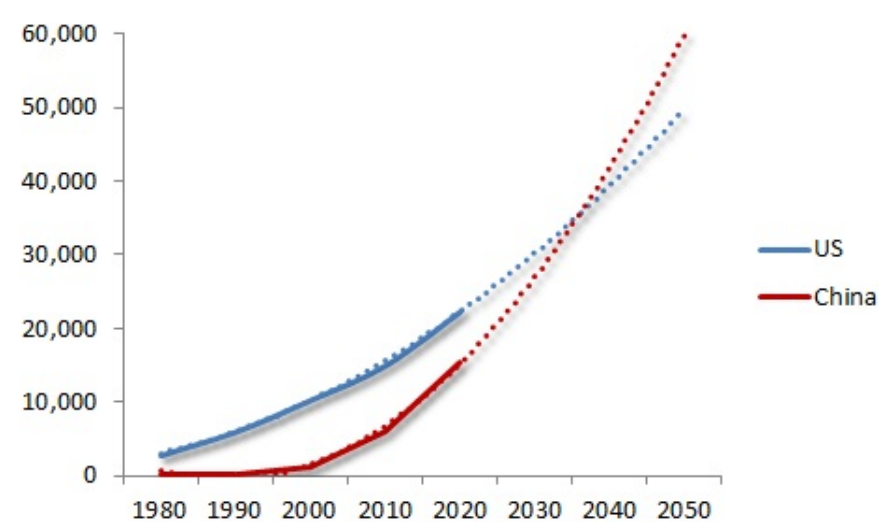

Fig. 2b. Expansion of U.S. and Chinese Economies, 1980-2050E Current Projection. Source: Difference Group.

technology. Even worse, bilateral frictions with China are spreading to U.S. trade conflicts with other North American Free Trade Agreement (NAFTA)

Lasting U.S.-China trade tensions may lead to serious global recession. members, Europe, East Asia and practically the rest of the world.

If the Trump administration continues moving away from the post-World War II trading regime, these bilateral frictions will broaden and multilateralize. And if a full- 
scale trade war cannot be avoided, then the nascent tariff wars have potential to spread across industry sectors and geographic regions. In fact, since the first half of 2018, the International Monetary Fund (IMF) growth projections have already been revised down for Europe, Japan, the United Kingdom, Brazil and India, among other major economies. The most important is how well the Chinese economy will do amid growing trade tensions with the United States. China accounted for almost 50 percent of global growth and continues to constitute some 30 percent of global prospects today. In positive scenarios, such economic spillovers support global growth. In negative scenarios, such spillovers would penalize those growth prospects and the collateral damage would likely be the worst in emerging and developing economies.

\section{Challenge to Global Economic Integration}

Recent globalization peaked between China's accession to the WTO in 2001 and the global financial crisis in 2008. After the crisis, China and large emerging economies fueled the international economy, which was thus spared from a global depression. But as Group of Twenty (G20) cooperation has dimmed, so have global growth prospects and the future of global economic integration. ${ }^{7}$

Before the global financial crisis, world investment soared to almost \$2 trillion. A decade later, global flows of foreign direct investment have fallen by almost 20 percent below the pre-crisis peak. ${ }^{8}$ In 2017, world merchandise trade recorded its strongest growth in six years. But due to rising trade tensions and increased economic uncertainty, the WTO warned that global trade growth is losing momentum and that downside risks have grown in the global economy. ${ }^{9}$ Following the financial crisis, there has been a

${ }^{7}$ Dan Steinbock, "The Great Shift: The Shift of Globalization from the Transatlantic Axis to China and Emerging Asia," China Quarterly of International Strategic Studies, Vol. 3, No. 2 (2017), pp. 193-226.

${ }^{8}$ UNCTAD, World Investment Report 2018. See also reports by Global Investment Trends Monitor.

9“World Economic Outlook Update, January 2017: A Shifting Global Economic Landscape," Market Screener, January 16, 2017, https://www.marketscreener.com/news/World-Economic-Outlook-Update-January-2017-A-Shifting-Global-Economic-Landscape-23702276/. 
dramatic fall in global finance as well. Meanwhile, global debt has continued to swell but has remained stable relative to world GDP (at about 169 percent) since $2014 .^{10}$

There is nothing inevitable about global economic integration. It may be useful to recall that, about a decade ago in July 2008, then-WTO DirectorGeneral Pascal Lamy declared that there was "qualified public support for globalization," and that "[g]lobalization will not come to halt."11 Only weeks later, trade depression spread across the world. Ten years later, Trump's tariff wars began to hurt a trade recovery that had taken a decade to materialize. In adverse conditions, they could even fuel serious global recession in the years to come.

\section{Worsening U.S. Perception of China}

When President Trump introduced the 2017 National Security Strategy, China was termed America's strategic "rival," even an "adversary":

For decades, U.S. policy was rooted in the belief that support for China's rise and for its integration into the post-war international order would liberalize China. Contrary to our hopes, China expanded its power at the expense of the sovereignty of others... Part of China's military modernization and economic expansion is due to its access to the U.S. innovation economy, including America's world-class universities. ${ }^{12}$

The new National Security Strategy turned the status quo realities upside down: first, the Trump administration began to question - if not outright reject - the post-World War II liberal international order that the United States and its allies had constructed in the postwar era; subsequently, the administration labeled China, along with Russia, as a U.S. "adversary,"

${ }^{10}$ Susan Lund et al., The New Dynamics of Financial Globalization (New York: McKingsey \& Company, August 2017), p. 11.

11 “The WTO Launches World Trade Report 2008: Trade in a Globalizing World," WTO Press Release, July 15, 2008, https://www.wto.org/english/news_e/pres08_e/pr534_e.htm.

${ }^{12}$ White House, National Security Strategy of the United States, December 2017, https:// www.whitehouse.gov/articles/new-national-security-strategy-new-era/. 
which allowed it to charge Beijing for efforts to undermine the postwar order. As a matter of fact, much of what was condemned was simply China's effort to replicate America's economic and strategic success through its peaceful rise. As long as full verification about China's alleged violations remains missing or requires blind faith in the U.S. intelligence community, it is not entirely clear to the Chinese side whether Washington seeks to contain China because China is violating international rules or because Washington aspires to sustain U.S. primacy.

As elite attitudes hardened, the public followed. According to a Pew survey, American attitudes toward China have become less positive over the past year. Overall, 38 percent of Americans have a favorable opinion of China, down from 44 percent in 2017. ${ }^{13}$ What the description does not mention is that, through the post-Cold War era, China-bashing has progressively got worse from Bill Clinton blaming George H. W. Bush for "coddling" with Beijing's leaders to Trump's crude allegation that "China is raping America." 14

However, Trump's trade views had little substantial basis. From a historical point of view, U.S. trade deficits had already begun in the early 1970s, three decades before the deficits with China. Indeed, U.S. deficits are historical, not recent; and multilateral, not bilateral. ${ }^{15}$ Also, conventional bilateral trade

\author{
Trump's trade \\ charges against \\ China lack \\ substantial basis.
}

\footnotetext{
${ }^{13}$ According to Pew, "attitudes toward China have fluctuated to some extent in recent years, becoming more negative during the 2012 election cycle, but more positive in 2017, before this year's decline." See Richard Wike and Kat Devlin, "As Trade Tensions Rise, Fewer Americans See China Favorably," Pew Research Center, August 28, 2018, https://www. pewglobal.org/2018/08/28/as-trade-tensions-rise-fewer-americans-see-china-favorably/.

${ }^{14}$ Nick Gass, “Trump: 'We Can't Continue to Allow China to Rape Our Country," Politico, May 2, 2016, https://www.politico.com/blogs/2016-gop-primary-live-updates-andresults/2016/05/trump-china-rape-america-222689.

${ }^{15}$ Trade deficits have prevailed more than four decades mainly with Asia; first with Japan, then with the newly industrialized Asian tigers, more recently with China and emerging Asia. It is only since the early 2000s that tensions between the U.S. and China have grown sharply.
} 
deficit data can be misleading due to global supply chains used by multinational firms. ${ }^{16}$ For instance, although Apple has no production of its own, most of its iPhone's value added accrues to the U.S. headquarters, and less than 5 percent to China. ${ }^{17}$ Furthermore, it is the overall size of the multilateral trade balance that really matters to the economy (not bilateral balances), and that balance is largely a function of macroeconomic forces, such as domestic savings and investment, not trade barriers. Nonetheless, during his 2016 campaign, Donald Trump pledged to challenge America's entire free trade past.

\section{From Trade Tensions to Trade War}

Following his election triumph, Trump began to "walk the talk." On his inauguration day, he announced U.S. withdrawal from the Trans-Pacific Partnership (TPP), which many saw as an Obama legacy, and pledged to renegotiate the NAFTA, a Clinton legacy. Following a year of tough rhetoric against China, he began the trade threats. In the process, he was guided by four advisers, ${ }^{18}$ each of whom had intimate ties with the U.S. steel industry and all had a track record of trade protectionism and, in some cases, of China-bashing.

At first, the trade hawks in the White House were contained by more mainstream policymakers like Secretary of State Rex Tillerson, Director of the National Economic Council Gary Cohn, and Treasury Secretary Steve

\footnotetext{
${ }^{16}$ Products may be invented or developed in one country and manufactured or assembled elsewhere using imported components from multiple foreign sources and then exported. Conventional U.S. trade data may not fully reflect the value added in each country and may be a poor indicator of the real beneficiaries of its global trade.

${ }^{17}$ Dan Steinbock, “Trading the Global Future II: Bad Policies," Georgetown Journal of International Affairs, August 31, 2018.

${ }^{18}$ The "four steel men" included Peter Navarro, Director of the White House National Trade Council, Trump's trade adviser Dan DiMicco, former CEO of the steel giant Nucor, U.S. Trade Representative (USTR) Robert Lighthizer, former Deputy USTR under the Reagan administration, and Secretary of Commerce Wilbur Ross, who made his estimated $\$ 700$ million in assets by buying bankrupt companies, especially in manufacturing and steel. See Dan Steinbock, "The Four Steel Men Behind Trump Tariffs," Difference Group Ltd., September 10, 2018.
} 
Mnuchin; it seemed that the world economy could avoid the path to protectionism. After their first summit at Mar-a-Lago in April 2017, President Trump and Chinese President Xi Jinping announced a 100-day plan to improve strained trade ties and boost cooperation, while agreeing on four high-level dialogues to replace those that operated during the Obama administration.

As the Chinese side began to explore areas of trade compromise, the White House undermined its stated plan. Thereafter, the high-level dialogues fell apart. Only days after the summit, Trump signed trade measures that were positioned to unleash a trade war by spring 2018. By then, Tillerson had been replaced by CIA chief Mike Pompeo, an assertive neo-protectionist. Cohn's Goldman Sachs companion Mnuchin proved weaker, while Secretary of Commerce Wilbur Ross leaned on winners regardless of the cause. As free-traders moved out, protectionists stepped in. Divisive talks and mixed signals endured from spring 2017 to early March 2018 when Gary Cohn resigned from the White House. That is when Trump moved from trade threats to trade war. In April 2018, the Trump administration introduced its first trade threats. In mid-June and late August followed the 25 percent tariff on $\$ 34$ billion and $\$ 16$ billion of Chinese exports, respectively. As China took retaliation by levying 25 percent tariff on $\$ 34$ billion of U.S. exports on July 6 and another $\$ 16$ billion on August 23, the U.S.-China trade war entered a more serious phase.

The early impact of China's tariffs on U.S. exports was likely to prove greater than that of U.S. tariffs on China's exports: $\$ 50$ billion represents 38 percent of U.S. exports to China, but only 10 percent of Chinese exports to the United States (Figure 3). Yet there is no winner in a trade war. Despite its retaliatory responses, China continued to push for diplomatic negotiation, along with efforts to import more American cars, aircraft and natural gas, while promoting reforms in its financial sector.

Since spring 2018, the United States has imposed three rounds of Section 301 tariffs on imports from China. By late 2018, China had responded by imposing retaliatory tariff hikes on U.S. goods valued at $\$ 110$ billion. China could also target U.S. economic

The U.S.-China trade war is largely driven by trade "hawks" in the Trump administration. 
China's exports to U.S.

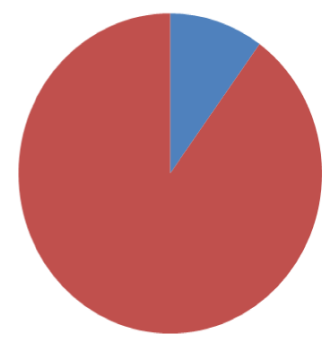

U.S. exports to China

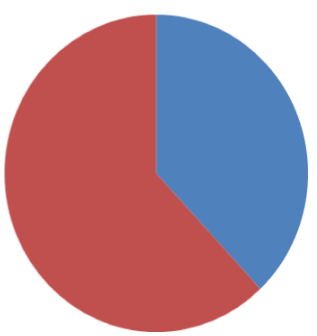

- Exports subject to possible new tariffs - Other exports

Fig. 3. Early Tariff War Hurt the U.S. More than China. Source: Standard \& Poor's.

Table 1. Section 301 Tariffs on Imports from China: Actual and Threatened Tariff Hikes.

\begin{tabular}{lccc}
\hline Date & Import Value & Tariff Hikes & China's Reaction \\
\hline July 6, 2018 & \$34 Billion & $25 \%$ & Full retaliation \\
August 23, 2018 & \$16 Billion & $25 \%$ & Full retaliation \\
September 24, 2018 & \$200 Billion & $\begin{array}{c}10 \% \text { (increased to } \\
25 \% \text { on } 1 / 1 / 2019)\end{array}$ & $\begin{array}{c}5-10 \% \text { tariff hikes } \\
\text { on } \$ 60 \text { billion worth } \\
\text { of imports }\end{array}$ \\
After trade talks deadline & \$267 Billion & & \\
Total & \$517 Billion & & \\
\hline
\end{tabular}

Sources: USTR Office; China's Ministry of Commerce; and Difference Group.

interests by other means, such as increasing regulatory scrutiny of U.S. firms in China. Tariff escalation could disrupt global supply chains and raise prices for U.S. consumers and firms that use Chinese imports, causing job losses. Even so, a fourth round of Section 301 tariffs was threatened prior to the truce between both countries in early December 2018 (Table 1). ${ }^{19}$

${ }^{19}$ As a result, a group of Republican senators introduced legislation that would provide Congress more power over any national security decision and to claw back trade power from Trump with legislation. See Vicki Needham, "Senators Introduce Bill to Change Process to Levy National Security Tariffs," The Hill, August 1, 2018, https:// thehill.com/policy/finance/399925-senators-introduce-bill-to-change-process-to-levy-national-security-tariffs. 


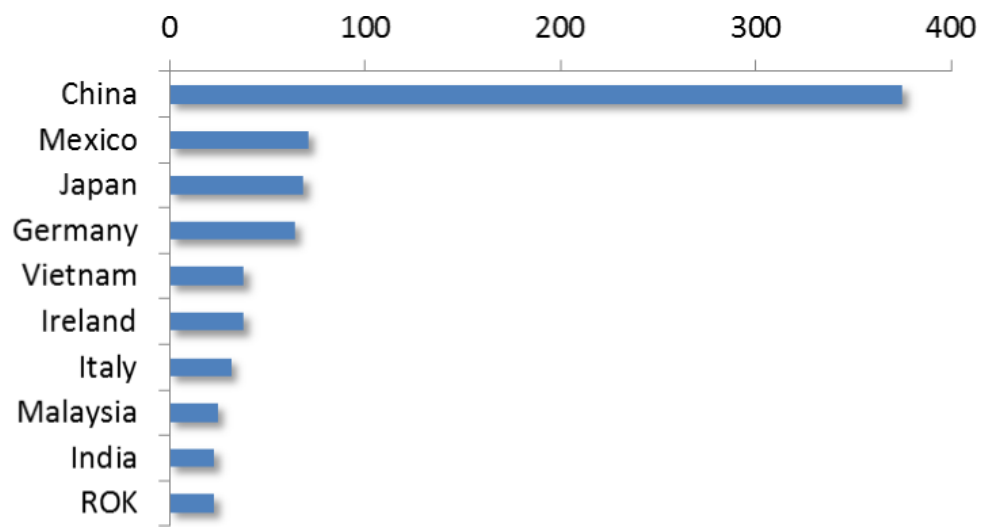

Fig. 4. U.S. Trade Deficit in 2017 (\$ Billion). Source: U.S. Census Bureau.

As President Trump ignored the needs of his constituencies, he paved the way to Democratic recapture of the House of Representatives in the 2018 mid-term election. ${ }^{20}$ At the same time, the U.S. tariff war with China began to multilateralize. The ultimate objective of the Trump administration seems to be targeted at America's deficit partners, in particular China, Mexico, Japan and Germany (Figure 4). Thus, when President Trump threatened to impose steep tariffs against the EU, German Chancellor Angela Merkel warned him not to unleash an all-out trade war.

If multilateral free trade is no longer what the United States seeks, what does the Trump administration want? The U.S.-Mexico-Canada Agreement (USMCA) signed on November 30, 2018 may serve as a blueprint of the White House's new muscular trade stance. To investors, businesses and consumers, the net effect means rising costs. The Agreement is

${ }^{20}$ Trump's methods alienated U.S. farmers, whose revenues have been penalized by the tariff war, and the powerful U.S. Chamber of Commerce. In July, Chamber President Tom Donahue launched a high-profile campaign against Trump's tariffs. See Renae Reints, "The U.S. Chamber of Commerce Is Fighting Trump's Tariffs with Facts," Fortune, July 2, 2018, http://fortune.com/2018/07/02/chamber-of-commerce-fights-tariffs/feed/. 
also mined with clauses designed against possible Canadian or Mexican deals with China. ${ }^{21}$

Trump aims to

unilaterally reverse

seven decades of

world trade

expansion.

In fact, the Trump administration might want to go even further. Trade adviser Navarro said that the United States could leave the WTO; ${ }^{22}$ and the White House has suggested that the United States may ignore WTO rulings that are not in its favor, amid alleged concerns that dispute settlement infringes on the U.S. sovereignty. ${ }^{23}$ There is a precedent. In the 1930s, Washington opted for the Smoot-Hawley Tariff Act to re-energize the U.S. economy. In reality, the Act made the Great Depression even worse, paving the way to World War II. If Trump's tariffs prevail and broaden, they would be at the level of those U.S. tariffs that last prevailed around 1945. With its "America First" stance, the Trump administration aims to reverse seven decades of world trade expansion in just seven months.

The early evidence on the impacts of the Trump administration's trade policy on prices and welfare is not reassuring. Even though the effective trade war covered only half of 2018, estimates for the full year indicate that the full incidence of the tariff falls on U.S. domestic consumers, with a reduction in U.S. real income of $\$ 1.4$ billion per month. Similar patterns have been identified for countries that have retaliated against the United States. Another estimate puts annual U.S. consumer and producer losses from higher costs of imports at $\$ 68.8$ billion ( 0.37 percent of the U.S. GDP),

${ }^{21}$ Dan Steinbock, "Will Trump Push for An 'America First' Trade Agreement in Asia Modelled on His New NAFTA Deal?," South China Morning Post, October 25, 2018.

${ }^{22}$ Mallory Shelbourne, "White House Trade Adviser Dodges Over US Leaving World Trade Organization." March 4, 2018, https://thehill.com/homenews/administration/376633white-house-trade-advisor-dodges-over-us-leaving-world-trade.

${ }^{23}$ Starting with the Obama administration, Washington has been blocking new appointments to the WTO's Appellate Body (AB). As more judicial terms are set to expire, AB may no longer meet its quorum after December 2019. See Dan Steinbock, "World Trade Organization at Risk," China-US Focus, November 16, 2018, https://www.chinausfocus.com/ finance-economy/world-trade-organization-at-risk. 
which translates into an aggregate welfare loss of $\$ 7.8$ billion (0.04 percent of GDP). ${ }^{24}$ Nevertheless, the tariffs - whether against commodities or services - may be just the first step in the Trump administration's agenda, in which the ultimate target is technology innovation and intellectual property rights (IPRs).

\section{Road to Trump's Technology War}

In mid-August 2017, President Trump asked USTR Robert Lighthizer to open an investigation into China's intellectual property (IP) practices. ${ }^{25}$ A veteran trade hawk, Lighthizer seized Section 301 of the Trade Act of 1974, which was used against the rise of Japan in the 1980s. Washington saw this effort presumably as an effort to restore "fair and free trade," and to "save" American innovation from "Chinese IP theft." This view united the White House's Goldman Sachs globalists and steel-industry protectionists. It was also supported by both Republicans and Democrats in the Congress. But is the narrative of Chinese IP theft at the cost of American innovation valid?

\section{U.S. IP Commission and the IP Theft Narrative}

The standard narrative is taken as self-evident in the United States. As the bestselling author Bob Woodward puts it: "The administration estimated China had committed $\$ 600$ billion in intellectual property theft." [Italics added by the author]. ${ }^{26}$ Similarly, when Wilbur Ross warned in the Financial Times in August 2017 that "American genius is under attack from China," he - like

${ }^{24}$ Mary Amiti et al., "The Impact of the 2018 Trade War on U.S. Prices and Welfare," NBER Working Paper No. 25672, March 2019; and Pablo D. Fajgelbaum et al., "The Return to Protectionism," NBER Working Paper No. 25638, March 2019.

${ }^{25}$ Office of the U.S. Trade Representative, “USTR Announces Initiation of Section 301 Investigation of China," August 18, 2018.

${ }^{26}$ Robert Woodward, Fear: Trump in the White House (New York: Simon \& Schuster, 2018), Chapter 33. See also Donald J. Trump, “Remarks on Signing a Memorandum on Addressing China's Laws, Policies, Practices, and Actions Related to Intellectual Property, Innovation, and Technology and an Exchange with Reporters," White House, August 14, 2017. 
the rest of Washington - resorted to the IP Commission's figures. ${ }^{27}$ All these views and estimates share a common denominator: they originate from the U.S. IP Commission, whose findings rest on data that remain largely "classified" in the name of "national security." Since the early 2010s, in parallel with the dramatic rise of Chinese innovation and outward direct investment as well as the U.S. "pivot to Asia," the Commission has argued that the plunder of American intellectual property is a systemic threat to the U.S. economy.

According to the Commission, U.S. IP theft "amounts [to] anything between $\$ 225$ billion and $\$ 600$ billion annually in counterfeit goods, pirated software, and theft of trade secrets." ${ }^{28}$ Curiously, while $\$ 600$ billion is stated as a (maximum) estimate of the global theft of U.S. intellectual property, that estimate is habitually attributed to China in international media.

Even though the Commission believes that the Chinese government "forces" U.S. companies to relinquish their IP to China, many U.S. IP experts that work on IP transactions in China find little evidence of such practices. $^{29}$ In regulated and strategic industries, Chinese overview is stringent, but that applies to both Chinese and foreign companies. Conversely, Chinese companies have faced many barriers in the United States in similar strategic areas, from CNOOC's failed effort to buy U.S. oil company Unocal (eventually acquired by U.S.-based

The U.S. IP

Commission is a partisan advocacy group for U.S. interests. Chevron) to Huawei's futile attempt to invest in America (which led to congressional hearings and a renewed political witch hunt in fall 2018). ${ }^{30}$

For years, foreign multinationals have been exchanging their technology expertise for market share in China (and several other $14,2017$.

${ }^{27}$ Wilbur Ross, "American Genius is Under Attack from China," Financial Times, August

${ }^{28}$ IP Commission, "Update to the IP Commission Report - Theft of American Intellectual Property: Reassessments of the Challenge and United States Policy," http://ipcommission.org/report/IP_Commission_Report_Update_2017.pdf.

${ }^{29}$ Dan Harris, "China-US Trade Wars and the IP Elephant in the Room," China Law Blog, August 30, 2017, https://www.chinalawblog.com/?s=Trade+Wars+and+the+IP+Elephant.

${ }^{30}$ Dan Steinbock, The Case for Huawei in America (New York: Huawei USA, 2012). 
large emerging economies). Semiconductors and Intel's industry dominance are a case in point. ${ }^{31}$ Today, former CEO of Intel Craig Barrett is one of the commissioners of the U.S. IP Commission, which is a partisan advocacy group for U.S. interests, as evidenced by its composition. For example, the Commission is co-chaired by Dennis Blair, former U.S. Director of National Intelligence and Navy admiral, and Jon Huntsman, Trump's former ambassador to Russia and China; and commissioners also include, among others, veteran senator Slade Gorton, whose focus is on economic and trade threats against America and anti-communist initiatives, ${ }^{32}$ and William J. Lynn III, former Deputy Secretary of Defense and a longtime lobbyist of Raytheon, a major defense contractor.

Just imagine a reverse case in which U.S. IP practices are challenged by a Chinese IP Commission that Chinese media would portray as independent but which is headed by a former admiral and intelligence director, an ex-Chinese U.S. ambassador, anti-U.S. leaders of China's People's Congress, and contractors of the People's Liberation Army. Imagine also that this Commission would rely on classified data in the name of Chinese national security. In that case, U.S. observers would be certain to argue that such a commission suffers from conflicts of interests, which undermines its independence. Precisely the same applies to the U.S. IP Commission. That is why such perception prevails that the trade war is just a poorly disguised effort to hinder China's rise in innovation. ${ }^{33}$

${ }^{31}$ Technology transfers increased significantly during the global financial crisis in 200709, when Intel, which then made over 70 percent of its sales outside the United States, opened a $\$ 2.5$ billion wafer fabrication foundry in Dalian in northeast China. The bet proved highly lucrative, especially amid the global crisis when Western economies plunged.

${ }^{32}$ These activities range from the "9/11 Commission" and the bipartisan Partnership for Secure America to the Slade Gorton International Policy Center funded by the National Bureau of Asian Research., which originates from anti-communist Senator Henry M. Jackson's initiatives.

${ }^{33}$ See Agnel Philip and Andrew Mayeda, "Trump Is Warned His Intellectual-Property Probe Risks a Trade War with China," Bloomberg, October 11, 2017, https://www.bloomberg.com/news/articles/2017-10-10/trump-warned-intellectual-property-probe-risks-chinatrade-war. 


\section{Changing Global Innovation Rivalry}

Another question concerns the timing of the IP confrontation amid a historical moment when Chinese multinationals are shifting from low-cost strategies to innovation and beginning to compete among world-class leaders, cutting-edge innovation and lucrative brands. Over a decade ago, I predicted that the then-conventional wisdom that China would remain "world's factory" was a myth. Emerging Chinese multinationals were "no longer satisfied with imitating. Instead, they seek to convert cost advantages to more sustainable competitive advantages - often through innovation." While the projection was ignored as unrealistic, it has proved accurate over time. ${ }^{34}$ Consequently, the Trump administration has resorted to political efforts to sustain U.S. primacy, which is no longer supported by the economic realities of innovation.

\section{Trump seeks U.S. primacy in innovation with political efforts.}

With regard to the number of total patent applications, China's role has exploded since the mid-2000s; and today it has left the United States, Japan, South Korea and Germany biting the dust (Figure 5a). Yet, not all patents are of equal value. The triadic patents, which are registered in the United States and the European Union, are most valuable. On triadic patents, China's power has increased six-fold in the past decade, yet it remains behind Japan, Germany and the United States (Figure 5b).

Much of China's IP progress can be explained on the basis of past technology transfer and the government's high investment in science and technology. Yet, in August 2017, only quarter of a year after the directives to assess the state of steel and aluminum imports to the United States, President Trump directed the USTR to determine if China's policies "may be harming American intellectual property rights, innovation, or technology development." In March 2018, the President signed a memorandum outlining USTR's findings, charging China for forced technology transfer, cyber-theft, discriminatory licensing requirements, and attempting to acquire U.S. technology to advance China's industrial power.

${ }^{34}$ Dan Steinbock, "New Innovation Challengers," The National Interest, January 3, 2007, https://nationalinterest.org/article/new-innovation-challengers-1361. 


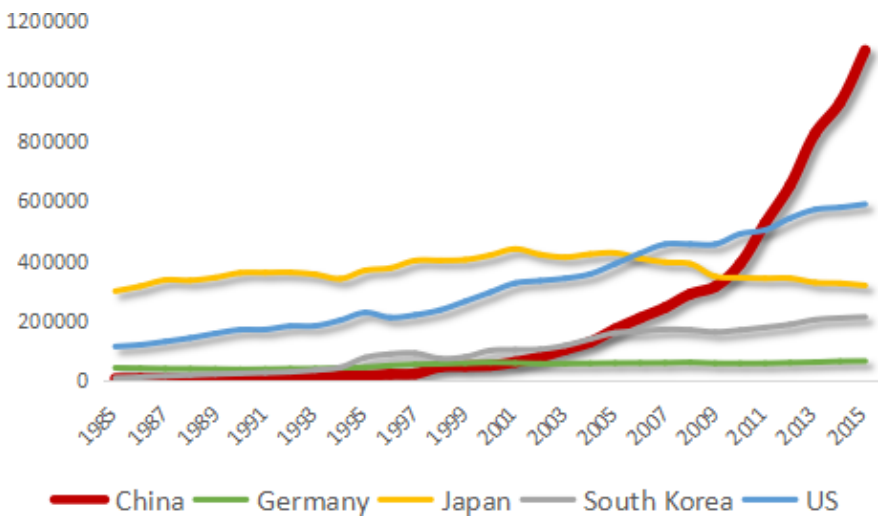

Fig. 5a. Global Innovation Rivalry: Total Patent Applications, 1985-2014. Source: WIPO.

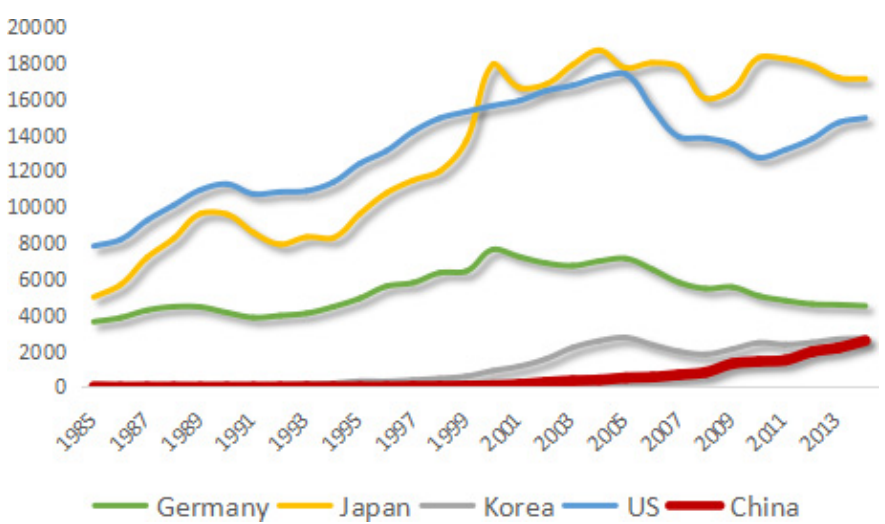

Fig. 5b. Global Innovation Rivalry: Triadic Patent Applications, 1985-2014. Source: OECD.

Since 2017, the White House has framed its policy toward China in terms of "great power competition." Its new initiatives look like a forceful attempt to revive postwar U.S. supremacy in a new century when old preconditions no longer prevail. Even if U.S.-China trade ties were to ease in the future, rivalry in technology and innovation would persist and intensify. In particular, there has been much speculation about potential relocation of parts of the electronics supply chain from China to emerging Southeast Asia.

However, the Trump administration has drastically underestimated the costs of shifting supply-chain ecosystems, which have taken decades to 
build and thus cannot change overnight. Some of these shifts would have happened anyway in the absence of a trade war, due to price competition in offshoring. But the U.S. tariff wars are likely to accelerate the process. The net effect is that such shifts in locations will not be driven by economic considerations, but by political contingencies, which will translate into additional producer costs, eventually falling on consumers. Ironically, tariff wars are likely to strengthen China's BRI initiatives in emerging Asia, which the Trump administration is opposing for political reasons.

\section{Trade-War Scenarios, Global Risks}

\section{From Harsh Rhetoric to Trade Talks}

The White House has left Beijing few alternatives but to target the U.S. export sectors that will suffer the most. ${ }^{35}$ China resorted to the WTO dispute settlement mechanism and took measures of equal scale and strength against U.S. products. ${ }^{36}$ Controversial options include Chinese currency valuation, although that could undermine the renminbi (RMB) internationalization. Even more consequential would be a Chinese move to sell U.S. treasuries. ${ }^{37}$

${ }^{35}$ In 2017, U.S. exports to China soared to $\$ 130$ billion. Only ten export groups accounted for more than half of the total, starting with civilian aircraft and engines (\$16 billion), soybeans ( $\$ 12$ billion), passenger cars ( $\$ 11$ billion) and semiconductors ( $\$ 6$ billion), followed by industrial machines, crude oil, and plastic materials.

${ }^{36}$ Tit-for-tat responses included soybeans in farm states, which voted for Trump in 2016. China could further ban the import of genetically modified products from the United States, which are already opposed by many countries. Beijing deferred trade and investment deals that had been signed during Trump's previous visit to China. As Chinese investments were obstructed in the United States, China could resort to tougher measures, such as enacting restrictions on imports of U.S. services.

${ }^{37}$ If China reduces its purchases of U.S. treasuries, the collateral damage would escalate in proportion to the pace and disruption of such reductions. In turn, rapid increases of gold reserves in Russia, China, and other economies precipitate new challenges against the U.S. dollar hegemony as concerns over U.S. stability are mounting worldwide. See Dan Steinbock, "The Great Dollar Debacle," World Financial Review, October 30, 2018, http://www. worldfinancialreview.com/the-great-dollar-debacle/. 
In turn, the Trump administration not only criticized China's economic practices, but linked them to China's longstanding military modernization effort. ${ }^{38}$ The administration's 2017 National Security Strategy describes China as a strategic "rival" and charges that it is pursuing a military modernization program that "seeks Indo-Pacific regional hegemony in the near term and displacement of the United States to achieve global preeminence in the future. ${ }^{39}$ In reality, the allegation projects on Beijing the aspirations of regional hegemony and global preeminence, a policy stance that was developed in Washington in the early 1990s and has been reflected in controversial U.S. actions thereafter. ${ }^{40}$ Moreover, the new U.S. strategy evolved amid the ongoing rearmament by the Trump administration. According to SIPRI research, the United States remains the country with the highest annual military expenditure in the world, whilst its international arms transfers accounted for 36 percent of the global total in 2014-2018. ${ }^{41}$

The trade war escalation casts a long dark shadow over the four newly established high-level dialogues between China and the United States, which are vital for strategic trust. ${ }^{42}$ Some unsubstantiated allegations have left even Chinese negotiators apprehensive. In the United Nations, Trump

${ }^{38}$ The association of Chinese economic practices with Beijing's longstanding military modernization became a major background factor informing U.S. defense strategy, budgets, plans, and programs. See Vice President Mike Pence's "Remarks on the Administration's Policy Towards China" at the Hudson Institute on October 4, 2018.

${ }^{39}$ White House, National Security Strategy of the United States of America, December 2017.

${ }^{40}$ Authored by then-Undersecretary of Defense for Policy Paul Wolfowitz and his deputy Scooter Libby for 1994-99, the document was leaked to the New York Times. See Patrick E. Tyler, “U.S. Strategy Plan Calls for Insuring No Rivals Develop," New York Times, March 8, 1992.

${ }^{41}$ U.S. arms exports in 2014-18 grew by 29 percent compared with 2009-13. See Pieter D. Wezeman et al., Trends in International Arms Transfers 2018, March 2019, https://www.sipri. org/sites/default/files/2019-03/fs_1903_at_2018.pdf.

${ }^{42}$ After the aggressive public attacks against China by both President Trump and Vice President Pence, the White House proposed that the Diplomatic and Security Dialogue be held for the second time in Beijing in October 2018. Unsurprisingly, China said its principals were not available. U.S. escalation followed a September 20 U.S. decision to sanction the Chinese military's Equipment Development Department for arms purchases from Russia, and the Administration's September 24 notification to the Congress of a $\$ 330$ million U.S. arms sale to Taiwan. 
accused China of "attempting to interfere" in the 2018 mid-term elections, but without any evidence for the allegation. ${ }^{43}$ Not so long ago, there was still relatively serious talk about the U.S.-China Bilateral Investment Treaty (BIT). Within months of trade war and asset divestitures, Chinese investment in mid-2018 was negative in the United States and collateral damage spread from goods to services. ${ }^{44}$ The trade war has spilled over to global supply chains and to educational and people-to-people exchanges, as student visas were denied in the name of national security. After the deterioration of bilateral ties in trade, IPRs, investment and exchanges, more risks loom ahead.

\section{The U.S. and China} may reach a trade deal based on enforceable Chinese commitments.

Nevertheless, some policy space remains for compromise. Following the G20 meeting in Buenos Aires, Trump agreed to leave tariffs on U.S. products at a 10 percent rate after January 1, 2019, while China agreed to buy a substantial amount of products from the United States. The White House also said that China has agreed to start purchasing substantial U.S. agricultural, energy, industrial and other products from the United States to reduce the trade imbalance, and that both countries agreed to try to reach an agreement on several trade issues "within the next 90 days." Due to trade disagreements, posturing and positioning, the truce deadline has been extended several times (talks continue at the time of this writing).

Through the trade talks, the United States pushed for a broad commitment focusing on China's economic practices, including participation of U.S. firms in certain industries and protection of the U.S. IPRs. Trade hawks such as Lighthizer and Navarro pressed for a pact that would allow U.S. tariffs on Chinese goods to snap back in case of violations, without permitting China to retaliate in response. Yet, both Chinese negotiators and the

43“Trump Accuses China of 2018 Election Meddling; Beijing Rejects Charge," CNBC, September 26, 2018, https://www.cnbc.com/2018/09/26/trump-accuses-china-of-using-tariffsto-meddle-in-2018-midterm-elections.html.

${ }^{44}$ Historically, advanced economies tend to enjoy service surpluses but goods deficits in trade, thanks to higher productivity and value-added. U.S.-Chinese trade ties are no exception. In 2017, U.S. service trade surplus with China was $\$ 38$ billion. 


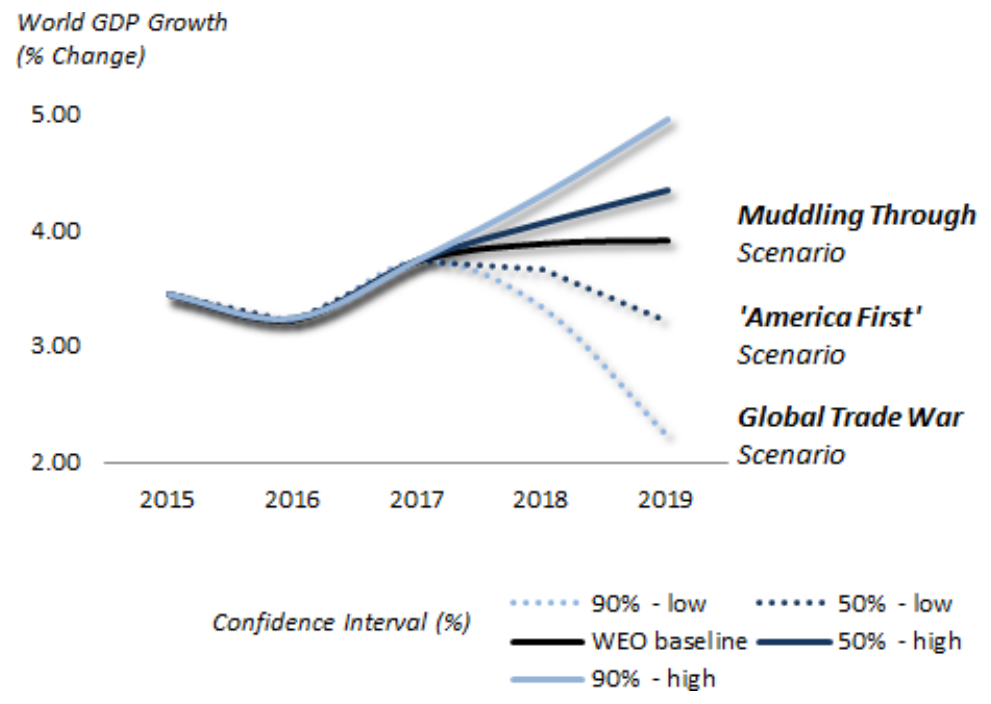

Fig. 6. Trade War Risks to Global Economy.

Sources: Difference Group (WEO/IMF growth data).

U.S.-China Business Council consider such a "condition" unfair or misguided. In contrast, U.S. business leaders were focused on the specifics of commitments and enforcement mechanisms. Even if a deal is signed, it will take another year or two to observe structural changes associated with the deal.

Since the global expansion has now passed its peak as a result of rising interest rates and global trade tensions, four generic scenarios could follow the U.S.-China truce in 2019 (Figure 6). The "Return to Cooperation" and "Muddling Through" scenarios represent variants of "recoupling." In these cases, global integration would prevail, despite rhetoric against cooperation and periodic falls in global integration. The "America First" and "Global Trade War" scenarios, however, represent variants of "decoupling," by which global integration would fail, either in part or fully and globally.

\section{The "Return to Cooperation" Scenario}

In this scenario, the United States and China achieve a trade agreement. Both agree to phase out additional tariffs, renounce trade threats and establish working groups to defuse other potential friction areas in industrial, intellectual property rights, social and political issues, and military matters. Real GDP growth in both countries begins to climb. Consequently, the 
global recovery, which was evident in 2017 and early 2018, resumes. Global growth prospects would exceed the OECD/IMF baselines at 4 percent or even higher. Nevertheless, this is the least likely scenario to materialize.

\section{There remains much}

uncertainty to

U.S.-China economic relations even after a deal is signed.

\section{The "Muddling Through" Scenario}

In this scenario, the tariff's economic impact would be limited to 0.4 percent of Chinese GDP and 0.8 percent of the U.S. GDP, respectively. The United States and China would develop a path to a trade agreement during the truce. Yet, other potential friction areas - particularly advanced technology — virtually ensure new skirmishes. Uncertainty decreases but fluctuates. Volatility grows erratic. Global economic prospects barely improve. Markets witness rallies and plunges. Global recovery fails to resume. Global growth prospects remain close to the OECD/IMF baselines at around 3.5 to 3.9 percent.

\section{The "America First" Scenario}

In this scenario, the import-value stakes would be 10-fold relative to the start of the trade war and amount to more than $\$ 0.5$ trillion, with soaring collateral damage. Neither would agree to phase out additional tariffs; both would renew trade threats. Talks would linger, fail or result in new frictions. Uncertainty increases and volatility returns. Global economic prospects decline further. Markets stagnate or even plunge. In this scenario, neither truce nor diplomacy would prevail. As a result, global prospects would dampen as world GDP growth in 2019 and later years would sink to 3 percent or worse.

\section{The "Global Trade War" Scenario}

In this scenario, all bets are off. The United States and China fail to agree on a trade compromise. Additional tariffs are enacted. New trade threats are declared. The White House escalates attacks against Chinese industries, intellectual property rights, social and political issues, and military modernization. Uncertainty escalates and volatility soars. Real GDP growth in the United States takes a severe hit, whilst Chinese growth erodes. The "Great Global Depression 2.0" begins to spread worldwide. Risks to global outlook overshadow world GDP growth, which, following the protracted 
global recession, would plunge to 2 to 2.5 percent for years to come, fueling plunging world trade and investment, as well as a series of new geopolitical conflicts.

The current situation is somewhere between the "Muddling Through" and the "America First" scenarios. Whilst there is still space for compromise and recovery, there is also room for more conflicts and further deterioration. It is important to recall that global growth has now halved from the pre2008 level, and that the current levels of global growth and trade have been more typical to historical periods of severe recessions and widespread conflicts. The question is: now that U.S. polls indicate that most Americans oppose tariff wars, what made these trade wars viable? The answer may have a lot to do with America's "imperial presidency" and its dark history.

\section{From Schmitt to Trump: Global Prospects of the U.S. Trade War}

As the controversial German jurist Carl Schmitt expressed in the 1920s, legal order ultimately rests upon the decisions of the sovereign, who only can meet the needs of an "exceptional" time and transcend legal order so that order can be reestablished. In his words, "Sovereign is he who decides on the exception." ${ }^{45}$ In the post-Weimar Germany, such ideas contributed to the eclipse of liberal democracy. Following September 11, 2001, such arguments renewed neoconservative interest in Schmitt and the "state of exception," which critics believe threatens to destabilize not only the law, but humanity in its entirety as well. ${ }^{46}$ In international relations, the ever present possibility that "friends" will act in expedient ways toward their "enemies" implies that the "status quo" is in a permanent state of exception. As Schmitt argued, those "enemies" will unite "us" against "them."

${ }^{45}$ Carl Schmitt, The Crisis of Parliamentary Democracy (Cambridge: MIT Press, 1923); Carl Schmitt, Dictatorship (Washington, D.C.: Polity, 2013). On Schmitt and international relations, see William Hooker, Carl Schmitt's International Thought: Order and Orientation (Cambridge: Cambridge University Press, 2009).

${ }^{46}$ Giorgio Agamben, State of Exception (Chicago: University of Chicago Press, 2005). See also George Schwab, The Challenge of the Exception: An Introduction to the Political Ideas of Carl Schmitt Between 1921 and 1936 (Santa Barbara: Greenwood Press, 1989).

${ }^{47}$ Carl Schmitt, The Concept of the Political (New Brunswick: Rutgers University Press, 1932). 
In this view, the U.S. response to 9/11 was not unusual because liberal wars are "exceptional." Rather, it was a typical manifestation of ever more violent types of war within the very attempt to fight wars which would end "war" as such. ${ }^{48}$

Similarly, it is politically expedient to legitimize a trade war in the name of "national security," which allows the sovereign to redefine a new order on the basis of a state of exception, accompanied by a new national security strategy that defines "friends" as "enemies" and "us" as victims, thus justifying the seeking of justice from "adversaries" — "them."

However, the logic of the state of exception still leaves open the question as to how the White House, as a sovereign, could establish a trade war with China when U.S. trade wars have been opposed by much of the Congress and by most Americans, including Trump constituencies. To explain this, we must invoke the unitary executive theory in American constitutional law, which deems that the President possesses the power to control the entire executive branch, based on Article Two of the U.S. Constitution that vests "the executive power" in the President. ${ }^{49}$ The first to make explicit reference to the "unitary executive" was the Reagan administration (which President Trump sees as a model). Typically, it was predicated on U.S. sovereign debt that had been soaring ever since the 1970s. ${ }^{50}$ In turn, the G. W. Bush administration made the unitary executive theory a

${ }^{48}$ Louiza Odysseos, "Crossing the Line? Carl Schmitt on the 'Spaceless Universalism' of Cosmopolitanism and the War on Terror," in Louiza Odysseos and Fabio Petito, eds., The International Political Thought of Carl Schmitt: Terror, Liberal War and the Crisis of Global Order (New York: Routledge, 2007), p. 126. For an alternative view, see Jason Ralph, America's War on Terror: The State of the 9/11 Exception from Bush to Obama (Oxford: Oxford University Press, 2013).

${ }^{49}$ Despite the wide acceptance of that general principle, there is disagreement about the strength and scope of it, i.e., in favor of a "strongly unitary" executive, or a "weakly unitary" executive.

${ }^{50}$ On September 29, 1987, Reagan issued a signing statement that declared: "If this provision were interpreted otherwise, so as to require the President to follow the orders of a subordinate, it would plainly constitute an unconstitutional infringement of the President's authority as head of a unitary executive branch." See Ronald Reagan, "Statement on Signing the Federal Debt Limit and Deficit Reduction Bill," The White House, September $29,1987$. 
common feature of signing statements. ${ }^{51}$ It allowed the Bush White House to judicially implement national-security decisions that would divide the Capitol Hill and that the majority of Americans would oppose.

In the case of Trump, the need for unitary executive power arose from the Mueller investigation, which restricted his strategic maneuverability to operate with the Republican Congress in 2017-18 but permitted actions that only required executive power, typically in tax and trade policy. It thus allowed him to judicially escalate a trade war in the name of

The U.S. may take more unilateral actions globally as Presidential power continues expanding. national security. ${ }^{52}$ In this view, efforts at a trade compromise may prove more challenging than anticipated. In the post-World War II era, many multilateral financial institutions — such as the World Bank and the IMF - were created to facilitate global trade and development. Today, all of them have become "America First" targets. During the 2008 crisis, Dominique Strauss-Kahn, then-chief of the IMF, still pushed for reforms in the global multilateral institutions. However, that is not the Trump administration's goal. Rather, it hopes to replace the old multilateral liberal order with the imposition of the "America First" doctrine across the developing world.

If the U.S.-China trade war is less about trade than about U.S. effort at economic and strategic primacy, no concession may suffice. In this view, the controversial actions by the White House against China during the trade truce - including "breaking stories" by the media, Huawei CFO detention, charges against "Chinese hackers," and so on - can all be seen as tacit means to undermine a trade compromise so that the sovereign can re-define the status quo on the basis of national emergency. The ultimate

51 “On 363 occasions, President Bush objected to provisions that he found might conflict with the president's constitutional 'authority to supervise the unitary executive branch."' See Dawn Johnsen, "What's a President To Do? Interpreting the Constitution in the Wake of Bush Administration Abuses," Boston University Law Review. Vol. 88, No. 2 (April 2008), p. 395.

${ }^{52}$ Dan Steinbock, "U.S.-China Ties in the Shadow of the Mueller Investigation," ChinaUS Focus, June 9, 2017, https://www.chinausfocus.com/foreign-policy/us-china-ties-in-theshadow-of-the-mueller-investigation. 
objective, however, is the unilateral imposition of the U.S. "national security exception" across all global trade. For instance, in defense of the steel and aluminum tariffs, the United States cited national security reasons, that is, it sees tariffs as necessary to ensure the long-term viability of the domestic steel and aluminum industries, which must meet U.S. national defense requirements, by protecting the industries from foreign competition. Indeed, the legal argument rests explicitly on a presumed "national security exception." 53

But if that is the case, why has such unilateral practice - and the "imperial presidency" behind it - grown even harder to challenge? Certainly, one of the key forces has been the U.S. campaign finance and the increasing role of "big money" in American politics. In particular, the Supreme Court 5-4 decision in Citizens United v. Federal Election Commission, which struck down a federal prohibition on independent corporate campaign expenditures, is one of the most controversial opinions in recent memory. For it basically permitted corporate power to override democratic power in the White House. ${ }^{54}$ As the historical gap between the wealthiest and the rest of Americans has widened, the few who hold one billion dollars or more in net worth have begun to play a more active part in politics, with serious consequences for American democracy. ${ }^{55}$

In this view, the U.S.-China trade and technology conflicts reflect postCold War America's preference for primacy doctrines. The likely global economic scenarios, which precipitate significant and potentially critical

\footnotetext{
${ }^{53}$ The Trump administration has argued that even if the steel and aluminum measures are inconsistent with U.S. obligations under the GATT (precursor of the WTO), a WTO adjudicator (e.g., a WTO panel) cannot examine whether the Section 232 measures violate the GATT because Washington considers the measures to be necessary for the protection of its "essential security interests" under GATT Article XXI — the so-called "national security exception." See Brandon J. Murrill, “The 'National Security Exception' and the World Trade Organization," CRS Legal Sidebar, November 28, 2018, https://crsreports.congress.gov/ product/pdf/LSB/LSB10223.

${ }^{54}$ Mark Green, Selling Out, How Big Corporate Money Buys Elections, Rams Through Legislation, and Betrays Our Democracy (New York: Regan Books, 2002); Robert C. Post, Citizens Divided: Campaign Finance Reform and the Constitution (Cambridge: Belknap Press, 2014).
}

${ }^{55}$ Benjamin I. Page, Jason Seawright, and Matthew J. Lacombe, Billionaires and Stealth Politics (Chicago: University of Chicago Press, 2018). 
risks ahead, have become viable with the exceptional use of executive power by the post-9/11 U.S. administrations. During the Trump era, the "state of exception" rule is predicated on "imperial presidency" which is supported by the new campaign finance and "big money." Relying on enemies for unity, it poses significant risks not just to U.S.-China relations, but to U.S. democracy and global economic prospects. 